\title{
Disputing Without the Force of Law
}

\author{
Laura Nader ${ }^{\dagger}$
}

Americans have no access to law for certain types of problems. Starting with Dean Roscoe Pound, commentators ${ }^{1}$ have documented the reasons for lack of access: entry to the legal system demands an amount of time, money, and knowledge that many people do not have; ${ }^{2}$ the courts have contrived devices to control their dockets; ${ }^{3}$ and certain harms have not been accorded a legal remedy. ${ }^{4}$ Proposed reforms to

$\dagger$ Professor of Anthropology, University of California, Berkeley. The author wishes to thank Christopher Shugart for invaluable assistance in the preparation of this article. For a more complete discussion of the subject of this article, see No Access to Law (L. Nader ed. forthcoming); in many respects, law review form is not conducive to the expression and development of ideas by persons trained in other disciplines.

1. E.g., Fox, Providing Legal Services for the Middle Class in Civil Matters: The Problems, the Duty, and a Solution, 26 U. PrTr. L. Rev. 811 (1965); Maguire, Poverty and Civil Litigation, 36 Harv. L. Rev. 361 (1923); Pound, The Adminisiration of Justice in the Modern City, 26 HARv. L. REv. 302 (1913).

2. Pound, supra note 1 , at 310-11. Commentators have observed that entry into the legal system also demands a willingness to submit to a complex and cumbersome procedure that may fail to address underlying problems and may prevent disputants from acquiring quick response after telling their own stories. E.g., AMErican Bar Association, Report of the National Conference on Minor Disputes Resolution 2 (1977) (prepared by F. Sander).

3. See Friedman, Legal Rules and the Process of Social Change, 19 Stan. L. Rev. 786, 798-810 (1967) (reviewing jurisdictional and procedural rules developed by legal system to control volume of litigation). But cf. Sykes, Cases, Courts, and Congestion, in LAw IN Culture AND Society (L. Nader ed. 1969) (judicial autonomy limits judges' desires to develop administrative devices to control dockets).

4. Some consumer complaints concern risks of harm that have not yet occurred but that still cause constant worry. See p. 1002 infra. In addition, although consumers may be misled by marketing schemes even if they do not complete a transaction, actual economic injury is usually required to sustain a legal cause of action. See Rice, Remedies, Enforcement Procedures and the Duality of Consumer Transactions Problems, 48 B.U. L. REv. 559, 561 (1968).

Although judicial and legislative inroads have expanded legal protection for consumers during the past two decades, D. RICE, Consumer Transactions 86-329 (1975), many such reforms have been criticized as inadequate. The Uniform Consumer Sales Practices Act, for example, is designed to provide restitution to consumers harmed by abusive sales practices, but it has been criticized for imposing sanctions only against knowing violations and for failing to create balanced incentives for settlement. Rice, Uniform Consumer Sales Practices Act-Damage Remedies: The NCCUSL Giveth and Taketh Away, 67 Nw. U.L. REv. 369, 375-82 (1972). Moreover, burdensome time limitations and costs of meeting notice requirements impede class action suits under this and other legislative provisions. See McCall, Due Process and Consumer Protection: Concepts and Realities in Procedure and Substance-Class Action Issues, 25 Hastings L.J. 1351 (1974).

The Truth-in-Lending Act, 15 U.S.C. $\$ \S 1601-1677$ (1976), is designed to guard against deceptive credit practices, but critics note the shortcomings resulting from its reliancc on disclosure requirements. E.g., Kripke, Gesture and Reality in Consumer Credit Reform, 44 N.Y.U. L. REV. 1, 2-9, $51-52$ (1969). The increasing stringency of products liability law 
address access problems have at times stimulated broad political movements. Thus, the small claims court movement, ${ }^{5}$ the regulatory movement, ${ }^{6}$ the legal services movement, including federally funded legal assistance and prepaid legal services, ${ }^{7}$ and the public-interest movement, ${ }^{8}$ have each promised to provide previously unavailable legal help. None of these efforts alone, nor all of them combined, has satisfied the demand for access to legal relief which, by the turn of the century, became acute for a range of problems arising in the everyday lives of individuals.

Scholarly discussions of the problem of access, and reform proposals, have seldom focused on what people actually do when they have complaints but no access to law. Citizen action-and inaction-outside the legal system must be reviewed to determine whether the inaccessibility of legal relief for some problems is a serious deficiency. One particular class of cases commonly falls outside the channels of access to law in this country-complaints about the defects in purchased items and public services that interfere with life as usual and that often go un-

offers little assistance to consumers with problems that are frequent and relatively inexpensive. D. RicE, supra, at vii.

The Federal Trade Commission (FTC) regulates deceptive and abusive consumer practices, but the Commission's focus on halting undesired conduct and its own workload and bureaucratic delays limit its ability to provide effective redress for individual consumers. See, e.g., Lurie, Consumer Complaints: A Proposed Federal Trade Regulation Rule, 5 J. L. REF. 426 (1972). Thus, even when legal relief may be available for some of the complaints described in this article, the practical barriers to effective redress can effectively interfere with access to law.

5. For a comprehensive discussion of the literature on small claims, see Yngvesson \&: Hennessey, Small Claims, Complex Disputes: A Review of the Small Claims Literature, 9 LAw \&: Soc'y REv. 219 (1975). Recent studies criticize the enforcement process used by small claims courts. See American Bar Association, supra note 2, at 309.

6. See D. Rice, supra note 4, at 6-10; R. WiEBE, The SEARCH FOR ORDER 164-95 (1967). For discussions of current movements to reform regulatory efforts, see Commission on Law and the Economy, American Bar Association, federal Regulation: Roads to Reform (1978) (exposure draft); Bruff, Presidential Power and Administrative Rulemaking, 88 YALE L.J. 451, 454-56 (1979).

7. Approximately 320 legal services programs in local communities throughout the country serve 29 million Americans who live at or below the poverty threshold determined by the Office of Management and Budget. Ehrlich, Giving Low-Income Americans Minimum Access to Legal Services, 64 A.B.A.J. 696, 696-97 (1978). The Legal Services Corporation was established to ensure that those who are otherwise unable to afford legal assistance have access to it. $I d$.

Group legal services plans seek to provide a range of legal services to middle-income recipients. Like group medical insurance, these plans spread the cost among a large number of people in order to minimize the cost to the individual participant. In August 1976, approximately 125 such plans covered an estimated 1,250,000 members from \$12 to $\$ 250$ per member yearly. Murphy, The Prepaid Legal Services Picture, 62 A.B.A.J. 1569, 1570 (1976). For a description of various bar-sponsored prepaid legal service plans, see Special Commission on Prepaid legal Services, american Bar association, Revised Handbook on Prepaid Legal Services (1972).

8. See Note, The New Public Interest Lawyers, 79 YALE L.J. 1069 (1970). 
corrected. What do Americans do with such complaints when they perceive that they cannot obtain legal relief?

This article considers the importance of these complaints and examines an array of alternatives to the legal system that has developed to process consumer and citizen grievances. A pervasive pattern of unsatisfied complaints and inadequate relief emerges from research on extrajudicial complaint settings. ${ }^{10}$ The article suggests some of the causes and societal consequences of this pattern of failure; ${ }^{11}$ it concludes that, at least in this country, ultimate access to the legal system is crucial if extralegal processes are ever to provide effective relief for consumer and citizen complaints.

\section{Complaints about "Little Injustices"}

\section{A. Why Care About Complaints?}

One reason for an interest in little injustices is that people care about them; they are a great part of everyday living in a consumption-oriented society. Another reason for an interest in such complaints is that ignoring them encourages criminal behavior: when complaints go unaddressed, producers are in effect stealing small amounts from large numbers of people and escaping sanctions for such behavior. Traditional techniques for dealing with unfair treatment simply are no longer in use. English towns in the Middle Ages could rely heavily on public opinion to deter abuses in the marketplace; dishonest craftsmen and merchants were paraded through the streets and placed in stocks for all to see, and their wares were publicly burned. ${ }^{12}$ In a modern, industrialized society dominated by large corporations and sprawling governmental bureaucracies, public opinion and interpersonal ties can no

9. Consumer dissatisfaction is increasing. A survey of consumer attitudes commissioned by the Sentry Insurance Co. in 1976 found that $61 \%$ of consumers interviewed thought that the quality of goods and services had worsened in the preceding 10 years, and $78 \%$ said that products did not last as long as they did a decade ago. Sentry Insurance Co., Consumerism at the Crossroads 22, 23 (July 1976) (available from Sentry Insurance Co., Stevens Point, Wis.).

10. This article draws on research conducted over the past eight years. See p. 1003 infra.

11. For one judicial appraisal of causes and consequences, see Johnson v. Avery, 393 U.S. 483, 491 (1969) (Douglas, J., concurring):

The increasing complexities of our governmental apparatus at both the local and the federal levels have made it difficult for a person to process a claim or even to make a complaint. Social security is a virtual maze; the hierarchy that governs urban housing is often so intricate that it takes an expert to know what agency has jurisdiction over a particular complaint; the office to call or official to see for noise abatement, for a broken sewer line, or a fallen tree is a mystery to many in our metropolitan areas.

12. Hamilton, The Ancient Maxim Caveat Emptor, 40 YALE L.J. 1133, 1152 (1931). 


\section{Disputing Without Law}

longer serve as effective mechanisms of social control. The increasing availability and complexity of goods and services create more occasions for things to go wrong, such as defects in products and delays in the provision of public services.

Lacking other effective methods for solving such problems, a citizen may hope for relief from the legal system. Yet individual complaints about consumer goods and governmental benefits seldom reach courts. ${ }^{13}$ Even if there is a plausible legal argument, the money, time, and knowledge necessary to pursue a claim through official legal channels may be beyond the claimant's reach. The consumer suffers from a doubly disadvantaged position: he has to bear the full cost of legal fees, while businesses can deduct litigation costs as a business expense $\mathrm{e}^{14}$ and the public bureaucracy's legal costs are ultimately paid by the consumer.

Speaking more generally, the legal system is seldom responsive in a complex industrial society to issues that affect the quality of everyday life. ${ }^{15}$ In fact, the legal system may define a problem as relatively unimportant if the monetary amount in controversy is small, if one of the parties is too poor to wage a legal battle, or if the issue itself simply seems to be trivial.16 Yet from other perspectives, such problems are important. From the vantage point of a low-income family expecting a baby, the landlord's failure to return a security deposit could impose severe damage to the family's well-being. ${ }^{17}$ If the legal system is un-

13. Many complaints seldom reach any third party. See Best \& Andreasen, Consumer Response to Unsatisfactory Purchases: A Survey of Perceiving Defects, Voicing Complaints, and Obtaining Redress, 11 LAw \& Soc'Y Rev. 701, 713-14 (1977) (only 3.7\% voiced complaints studied reached any third party; only $16 \%$ of those brought to third parties were brought to lawyer or court).

14. Legal expenses incurred in producing or collecting income and managing incomeproducing property are deductible under I.R.C. $\$$ 212. See, e.g., Commissioner v. Estate of Bartholomew, 4 T.C. 349, appeal dismissed, 151 F.2d 534 (9th Cir. 1945).

15. See The Disputing Process: LAw in Ten Societies 38 (L. Nader \& H. Todd eds. 1978 ) ; L. Nader \& Combs-Schilling, Restitution in Cross-Cultural Perspective, in REstrTution and Criminal Justice 27 (J. Hudson \& B. Galaway eds. 1977).

16. See R. SMrrh, Justice and THE Poor 41 (1924) (“Our legal system has taken too literally the ancient maxim, 'de minimis non curat lex.' ")

17. Chief Justice Burger has observed:

[W]e do not need to call on psychiatrists or clinical psychologists to tell us that a sense of injustice rankles and festers in the human breast and the dollar value of the conflict is not always the measure of tension and irritation produced. A landlord who delays unduly in repairing a defective radiator or refrigerator can produce unhappy chain reactions on children and adults. A defective roofing or siding job on the home, defective work on the family car sometimes can produce serious consequences comparable to those of a major illness.

Burger, Our Vicious Legal Spiral, Judges' J., Fall 1977, at 48; see Small Claims Study Group, Little Injustices: Small Claims Courts and the American Consumer 5 (1972) (J. Weiss, project director) ("The person of modest income, barred from seeking redress for a real grievance by the cost of legal assistance, may feel a sense of powerlessness just as great as the unattended patient.") 
responsive to such everyday problems, it becomes irrelevant to its citizens. If the alternatives to legal relief are also ineffective, the inadequacy of law is felt even more profoundly. ${ }^{18}$ What may seem to be a minor problem thus can be significant because its resolution-or lack thereof-influences people's attitudes about law and social order.

Further, complaints about little injustices may serve to signal broader problems affecting many people. Even though companies may tend to believe that people use general complaints as a strategy to solve an individual problem, people often complain in order to encourage the company to change its production policy or improve the quality of its product. ${ }^{19} \mathrm{~A}$ company that ignores or misunderstands such complaints may fail to perceive the seriousness of underlying product defects. Such was the case when one woman complained to a company that made diapers that distintegrated in use. She asked that the company do something to guard against the risk that a child might swallow a piece of diaper and choke to death; she received in response a new box of diapers. 20

An examination of numerous similar individual complaints in the aggregate may expose the extent of a problem and highlight the need for a systemic response. Consumer complaints can alert regulatory agencies to the widespread presence of product defects. For example, problems encountered by women and minorities who attempt to obtain credit can become apparent through examination of the level of individual complaints registered at the FTC. ${ }^{21}$ If all individual com-

18. In this sense, judicial and extrajudicial mechanisms can be seen as parts of one interrelated system of social control; together, they define the availability of solutions to people's problems.

19. A review of over 5,000 complaint letters revealed that people of all socioeconomic brackets write such letters and that they are often motivated by a sense of injustice and a desire to improve products, as well as by a desire to have their own loss redressed. See $\mathbf{L}$. Nader, Introduction to No Access to Law (L. Nader ed. forthcoming) [hereinafter cited without cross-references as No Access to Law].

20. Id. A similarly inadequate response occurred when a complainant convinced the New York Department of Consumer Affairs to respond to a company's fraudulent discbrake special. The Department simply imposed a \$50 fine on the company; it did not put an end to the scheme. Id.

21. The FTC, the agency with overall enforcement authority under the Equal Credit Opportunity Act, 15 U.S.C. $\$ 1691 c(c)$ (1976), receives consumer complaints and inquiries regarding the vast majority of the creditors affected by the Act; other complaints are directed to other agencies. Although the FTC does not intervene in individual disputes regarding credit rejections, it responds to consumer inquiries. The agency files all inquiries and complaints under the complainant's name, the name of the creditor, and the statutory provision that governs the problem described in the complaint. Although the FTC does not tabulate complaints, FTC attorneys try to investigate creditors about whom large numbers of complaints accumulate or who appear to be engaged in particularly egregious violations. Telephone Interview with Jean Noonan, attorney, Division of Credit, FTC (Feb. 5, 1979). 
plaints to congressional representatives about social security were channeled from case-work staff to legislative action, perhaps the entire benefit system would be streamlined. This aggregate approach to individual complaints is seldom taken, however, partly because politicians benefit personally from the handling of cases individually and because complainants rarely see themselves as members of a class sharing the same problems.

\section{B. Studying Complaints}

A systematic study of people who voice complaints in extrajudicial settings was launched eight years ago. ${ }^{22}$ Locating complainants for study is difficult because they are dispersed and often hidden by virtue of the confidentiality maintained by companies and nonjudicial disputesettlement mechanisms. ${ }^{23}$ After reviewing several hundred letters sent to a national citizen-action organization, ${ }^{24}$ the study focused on the complainant's perspective on organizations whose manifest goal is to handle complaints. A team of researchers used participant-observation methods and other data-gathering techniques employed by anthropologists to acquire a panoramic view of the range of mechanisms that has been developed to handle complaints about products and services. In recent years, such programs have sprouted in the form of city consumer departments, consumer fraud divisions of attorneys general offices, private company toll-free hotlines, advertising review boards, professional associations, consumer complaints centers, media action lines, and neighborhood legal services. Some institutions developed by the business community were selected for detailed examination: a branch of the Better Business Bureau (BBB),25 the consumer-action

22. Following preliminary study, in 1973 a proposal was submitted to the Carnegie Corporation from the Center for the Study of Responsive Law in Washington, D.C., for the establishment of a Consumer Complaint Research Center. The purposes of such a research center were to learn in greater detail about the actual operation of existing grievance mechanisms and to determine American attitudes about these processes. The work was conducted jointly by the Center and the University of California, Berkeley.

23. As testimony to the attempt of companies to keep complaints secret, General Motors displayed avid interest in buying 19 boxes of microfilmed complaint letters originally sent to the Chevrolet customer relations department that accidentally wound up in the hands of two scrap dealers. It would be overgenerous to presume that GM quickly paid $\$ 20,000$ out of a desire to better understand the nature of customer dissatisfaction. See San Francisco Chronicle, Apr. 29, 1971, at 2, col. 1.

24. Freedman, "Dear Mr. Nader": A Study of Consumer Complaint Letters, in No Access to Law. Freedman's study analyzes recurrent patterns in several hundred complaint letters written directly to Ralph Nader, or written to corporations or government agencies with carbon copies sent to Mr. Nader.

25. Eaton, The Better Business Bureau: "The Voice of the People in the Marketplace," in No Access to Law. Beginning in 1971, Eaton analyzed the performance of a BBB branch. Her study substantiates a congressman's findings that documented the tension 
panels sponsored by six trade associations, ${ }^{26}$ and the complaint-management systems developed by six urban department stores to satisfy steady customers. ${ }^{27}$ The open-return policy adopted by some of these stores was also examined. ${ }^{28}$ In addition, the research team studied the Public Review Board of the United Auto Workers-another institution managed directly by the organization complained about.. ${ }^{29}$ Although the union does not deal with either product or service complaints, its board is reputed to be the best developed mechanism for handling worker-

between the BBB's financial dependence on local businesses and its goal of serving consumers. See 117 CoNG. REc. 47,781 (1971) [hereinafter cited as Rosenthal Report].

The BBB remains one of the most frequently used complaint-processing mechanisms. A 1974 Roper Report asked consumers where they would turn should they fail to get satisfaction from a seller or manufacturer. Over $50 \%$ responded that they would go to the BBB. Conference Board, The Consumer Affairs Department: Organizations and Functions 6 (1973); see D. King \& K. MaEvoy, A National Survey of the ComplaintHandling Procedures Used by Consumers (1976) (Nat'l Technical Information Serv., U.S. Commerce Dep't) (BBB more familiar to consumers than 19 of 21 public and privatc organizations; only Post Office and Social Security Administration better known).

26. Greenberg \& Stanton, Business Groups, Consumer Problems: The Contradiction of Trade Association Complaint Handling, in No Access to Law. The research for this study was conducted from 1974 to 1976.

Consumer action panels aim to decrease overt dissatisfaction at the smallest cost and without alienating the businesses that constitute their memberships. Their purpose is to forestall government regulation through industry self-regulation. Id. For another discussion of complaint handling by trade associations, see Jones \& Boyer, Improving the Quality of the Marketplace: The Need for Better Consumer Remedies, 40 Geo. Wash. L. Rev. 357, 370-72 (1972).

27. Karikas \& Rosenwasser, The Department Store: Face-to-Face Complaint Management, in No Access to Law. This study was carried out in 1972. The rescarch is particularly interesting because it deals with complaints directed against the seller. One survey found that $87 \%$ of households that complained went to the seller first. See D. King \& K. McEvoy, supra note 25, at 10 . Best and Andreasen found that only $3.7 \%$ of all complaints were taken to third parties, and noted that "[t]he limited role of third parties suggests that our first priority should be improvement in the way sellers handle complaints." Best \&. Andreasen, supra note 13 , at 132 .

28. Despite the commonly expressed fear that an open-return policy would produce an avalanche of unsubstantiated complaints that in turn would reduce corporate profits, the study's preliminary review of retailers and manufacturers found numerous businesses that have maintained such a policy and still earned respectable profits. E.g., Telephone Interview with Gordon Serman, former president of Midas Muffler (Apr. 22, 1974); Interview with regional spokesman, Sears Roebuck, Inc. (Oakland, Cal., Oct. 3, 1978). Sears Roebuck has used an open-return policy since the 1890s, and has also instituted a system for identifying and dealing with patterns of complaints. Id. Reports on every complaint are sent to the Sears headquarters in Chicago and compiled. Sears then tries to work with manufacturers to improve products that continually fail to satisfy customers. The openreturn system gives each store an increased incentive to carry only products that will please. Id.

29. See Combs-Schilling, Grieving and Feuding: The Organizational Dilemma of a Labor Union, in No Access to Law.

Combs-Schilling studied the UAW's formal mechanisms for handling complaints during two separate periods: in 1973 , when the auto industry was in relatively good health, and in 1975, when it was not. In describing the procedures used for processing complaints, she notes that they resemble American legal procedures in their formality and complexity: they include the initiation of charges, the choosing of a trial committee, a trial, and several levels of appeal. Her most important finding is that the system was hardly ever used. $I d$. 
union complaints; it was chosen for study with the hope that some of its ideas could be applied to the handling of consumer complaints.

Other complaint-processing devices use an intermediary to act as a clearinghouse, troubleshooter, or watchdog. Two such programs received close consideration: the handling of constituent complaints by the district office of a popular United States congressman, ${ }^{30}$ and the Policy Service Bureau (PSB) of the California Department of Insurance. ${ }^{31}$ San Francisco Consumer Action, a private voluntary organization created to help citizens with their grievances, was also researched in depth..$^{32}$ Another study compared a business organization, a private voluntary organization, and a city government organization as they operate in a Washington, D.C. ghetto. ${ }^{33}$ Finally, four media action lines that solicit and pursue complaints were examined. ${ }^{34}$

Each of these techniques is devoted to receiving and responding to an individual's dissatisfaction with a product or service; each is supposed to offer speedy, simple, and inexpensive access to relief. At various times, some of the devices have successfully satisfied individual complainants. Department-store customers-especially those with good credit records-who persist in their complaints by confronting upperlevel management can obtain favorable resolution..$^{35}$ The congressman's wide network of influential contacts enabled him to process constituent complaints effectively. ${ }^{36}$ San Francisco Consumer Action added pro-

30. Karikas, Solving Problems in Philadelphia: An Ethnography of a Congressional District Office, in No Access to Law; see W. Gellhorn, WheN AMEricans Complain: Governmental Grievance Procedures (1966). Congressman William Barrett, who held office from 1945 to 1946 and from 1949 until his death in 1976, operated in the style of the political machine that in the past prevailed in many cohesive ethnic communities in American cities. Machine politics were based on reciprocal favors within the local ward: Barrett's constituents delivered the votes in return for his personal aid. Id.

31. See Serber, Resolution or Rhetoric: Managing Complaints in the California Department of Insurance, in No Access to Law. Research on the Department was completed during 1971 and 1972. The Insurance Department is the only agency, public or private, in California that takes complaints about insurance; it is authorized to suspend an insurer's state certification upon a finding of unfair practices. Most of the Department's work is conducted by an insurance officer who mediates between the customer and the company. Id.

32. See Wilson \& Brydolf, Grass Roots Solutions: San Francisco Consumer Action, in No Access to Law. A study by Wilson in 1973 was followed up three years later by Brydolf. The organization had undergone significant changes during that time. Id.

33. Greenberg, Easy Terms, Hard Times: Complaint Handling in the Ghetto, in No Access to Law (comparing Consumer Development Group and Service Area Committee (SAC), and a department store, all in Washington, D.C.).

34. Mattice, Media in the Middle: A Study of the Mass Media Complaint Managers, in No Access to Law. The media action lines studied included one managed by a newspaper, one associated with a television station, and two associated with radio stations. The research was initiated in 1972. By the early 1970s, over 350 action-line columns appeared in newspapers alone. Id.

35. Karikas \& Rosenwasser, supra note 27.

36. Karikas, supra note 30. 
grams to its switchboard hotline to promote public education, train consumers to help themselves, and undertake political lobbying demonstrations. ${ }^{37}$ Public faith in the organization was always very high; in a survey, eighty-eight percent of complainants polled said that they trusted the organization. ${ }^{38}$ Media action lines sometimes have publicized recurrent complaints about business and government, and have stimulated corrective action. ${ }^{39}$

Yet in spite of particular successes of some of these organizations, in general a rather dismal pattern emerges from the study. Instead of providing easy access to swift relief, many of the programs obstruct the complainants' path with complex procedures ${ }^{40}$ and repeated delays. ${ }^{41}$ Some fail to disclose to the complainant the steps necessary in order to process a grievance; ${ }^{42}$ some department stores even hide their customer-service offices from view. ${ }^{43}$ Intermediary organizations are often understaffed, underfinanced, and overworked, ${ }^{44}$ and the resulting backlogs and inefficiency can discourage consumers from pressing their complaints. ${ }^{45}$ There is evidence that some organizations deliberately dissuade individuals from pursuing relief. ${ }^{46}$ In sum, complaint-processing methods often make it so difficult for complainants to persist that they are likely to "lump it," 47 and even likely to avoid raising claims in the future. ${ }^{48}$

37. Wilson \& Brydolf, supra note 32.

38. Id.

39. Mattice, supra note 34 .

40. E.g., Combs-Schilling, supra note 29 (union workers may be discouraged by paperwork involved in trial-type complaint procedures).

41. E.g., Greenberg \& Stanton, supra note 26 (resolution of complaints by trade association panels takes months, "especially when the panels needlessly send consumers back to dealers or manufacturers").

42. Combs-Schilling, supra note 29 (union workers uninformed about available procedures); Greenberg \& Stanton, supra note 26 (trade association panels do not systematically inform unsatisfied complainants that they can continue to pursue relief).

43. Karikas \& Rosenwasser, supra note 27 (complaint departments often on top floor of store; customer service sign at one store partially hidden).

44. E.g., Serber, supra note 31.

45. Id.

46. Greenberg, supra note 33 (ghetto store that sells on credit and deals with customer complaints about payment terms uses intimidation as last resort to prevent customer from complaining to third party); see Eaton, supra note 25; Greenberg \& Stanton, supra note 26 .

47. "Lumping it" refers to the failure of an aggrieved party to press his complaint so that the problem that gave rise to the disagreement is ignored. Felstiner, Influences of Social Organization on Dispute Processing, 9 LAw \& Soc'Y REv. $63-94$ (1974). This behavior is typical of persons who lack access to information or to law, and persons who perceive that the costs of pursuing a complaint are too high or that the potential gains are too low. See Galanter, Why the "Haves" Come Out Ahead: Speculations on the Limits of Legal Change, 9 LAw \& Soc'y Rev. 95, 124-25 (1974).

48. The self-reported success rates of complaint organizations are thus often misleading because of the large number of persons who initially seek assistance and then drop out. In a 1975 report, for example, one trade-association complaint panel claimed that $97 \%$ of 
A survey of 2,419 respondents in 34 cities was conducted in 1975 in order to discover how consumers respond to unsatisfactory purchases. ${ }^{49}$ A remarkable finding was that buyers did not complain at all about 57.7\% of their problems that concerned more than only price. In $30.7 \%$ of the cases in which buyers perceived problems, the only complaint made was to the seller. In only $1.2 \%$ did the buyer take his grievance to a third party. One might think there was no need to resort to third parties because the sellers were so quick to give redress, but the data show otherwise. Only $56.5 \%$ of the voiced complaints-disregarding the few that concerned only price-were settled to the satisfaction of the purchaser. This means that many consumers who complained to the seller without success did not contact a third party. One reason for consumer reluctance to complain to third parties is the improbability of success.

The failure to devise successful processes to receive and respond to complaints is even more severe when measured against the societal benefit that could accrue if complaints were handled satisfactorily. Besides resolving individual grievances quickly and fairly, an ideal complaint-handling system would disclose aggregate patterns of abuse or injustice and would support systemic reform. An ideal system would improve the quality of goods and services by alerting producers about defects and by providing administrative agencies with data to guide and support enforcement. The systems that exist, however, do not prevent or deter abuses. At best, they satisfy isolated individuals ${ }^{50}$ and only rarely is systematic reform stimulated.

The remainder of this article examines the results of our study which revealed the inadequacy of complaint processes in nonjudicial settings. It identifies competing constituencies and structural flaws that contribute to the limited responsiveness of complaint-handling systems.

\section{Constraints on Third-Party Complaint Handlers}

A few years ago I attended a ceremony in San Francisco to celebrate the opening of a complaint-mobile by the city district attorney's office.

its cases were resolved during the first phase of its procedures. Greenberg \& Stanton, supra note 26. Less than half, however, were actually resolved in a way that the complainants considered satisfactory. Id.; cf. R. Darmstadter, All You Ever Want to Know About the Office of Consumer Affairs (unpublished 1973) (on file with Yale Law Journal) (White House Consumer Office labeled complaint procedure "success" whenever company responded to inquiry).

49. See Best \& Andreasen, supra note 13.

50. See, e.g., Karikas \& Rosenwasser, supra note 27 (individual complaints at department stores rarely affect general store policy and rarely reach manufacturers); Karikas, supra note 30 (congressman handled cases on isolated basis and did nothing to create lasting changes that would avoid identical future complaints). 
On a city street, the public was invited to present their complaintsaccess was certainly easy. An agitated woman hurried forward and sat down in front of the complaint handler. "I haven't received my social security check for six months," she said. The complaint handler put down her pencil: "I'm sorry, we don't handle social security problems." The woman walked away. There was a problem of misleading advertising; the sign on the truck did read "Complaint-Mobile."

This anecdote is not an isolated example. It summarizes problems inherent in most complaint-handling devices: they are not tailored to the needs of individual users. False expectations are encouraged in the advertising and labeling of complaint mechanisms. Those expectations are disappointed in the actual provision of services. This pattern perhaps should not be surprising. It replicates the problems of consumer goods and services that give rise to complaints. From the automobile industry ${ }^{51}$ to public educational systems, ${ }^{52}$ technology often is not designed to meet the needs or constraints of the individual user.

The plight of the consumer to some extent was created by the disintegration of a market system of exchanges between parties having equal power and information. ${ }^{53}$ Government regulation designed to protect the consumer constitutes one attempt to compensate for market disintegration..$^{54}$ Complaint mechanisms, at least overtly, constitute another. The development of these mechanisms suggests that individuals need the additional leverage offered by intermediaries to register their interests and to obtain satisfaction. On closer examination, however, it appears that complaint handlers in fact do not compensate for the inequalities that impair the operation of a market system. Instead, complaint handlers reinforce those inequalities and respond to interests other than those of individual complainants. Seldom funded or created by complainants, complaint mechanisms are able to survive without responding fully or successfully to consumer or citizen grievances. As a result, most extrajudicial settings for resolving consumer and citizen complaints deliberately or unintentionally discourage complainants and diffuse pressures for systemic change.

51. See R. NADER, UNSAFE AT ANY SpeEd (1965) (describing design deficiencies of Corvair and Mustang automobiles).

52. See, e.g., D. TYAK, ThE ONE BesT SYSTEM 39.59 (1974) (historical roots of educational systems designed to promote order and conformity).

53. For general discussions of the rise of giant corporations and the transformation of the traditional market system, see J. Galbraith, Economics and The Public Purpose 38-5I (1973); R. Heilbroner, The Wordly Philosophers 252-76 (2d ed. 1961); G. Lodge, The NEW AMERican IDEology 234-64 (1975).

54. See, e.g., Fair Packaging and Labeling Act, 15 U.S.C. \$§ 1451-1461 (1976); Truth in Lending Act, $i d$. $\$ \$ 1601-1677 ;$ M. Weidenbaum, Business, Government and the Public 24-59 (1977) (reviewing consumer-product regulation). 


\section{A. Powerful Interests v. Individual Complainants}

Organizations are attentive to the people who provide for their funding and continued survival. When these supporting organizations have interests contrary to those of complainants, the complaint mechanisms will have at best limited effectiveness. Even absent conflicting interests, patrons who do not share the goals of complainants can distract the organization from satisfying complainants. This pattern appears in media action lines, in self-regulation efforts of the business community, and in programs sponsored by governmental agencies.

Media action lines have the capacity to act as intermediaries, to take advantage of informal networks of favors, to create bad publicity, and to translate complaints into calls for general reform. ${ }^{55}$ Yet, regardless of the action line's independence from the parent newspaper or broadcaster, it will be constrained by the goals of its media host: pleasing the audience and the advertisers. Although obtaining a solid victory for a consumer can make good news, complaints may be rejected because they are repetitive and no longer engage the audience. ${ }^{56}$ Furthermore, the interests of advertisers can ultimately supervene those of both the audience and the consumer. The staff of one television action line was told to discontinue the use of company names because advertisers felt threatened. ${ }^{57}$ An auto association in Atlanta reacted to a local television station's proconsumer broadcasts with a one-year advertising boycott. ${ }^{58}$ Thus, media action lines may disregard the interests of consumers in order to maintain their primary audience and to avoid antagonizing their benefactors, the business community.

Self-regulation efforts established by the business community in response to consumer complaints are even more directly tied to the

55. Mattice, supra note 34 . The intermediary role served by action lines resembles a function performed in other legal systems. See Barton, Igugao Law, 15 U. CaL. Publications in AM. ARchaeology \& EthNology 1, $57-58$ (1919) (all important transactions consummated with aid of intermediary). For example, "Action 4," part of a television news program in New York City, had trouble convincing a department store to settle consumer complaints until reporter Betty Furness discussed the problem on the air. N.Y. Times, Mar. 29, 1976, at 55, col. 1 .

56. An advertisement placed in a newspaper by "Action 7 " of KGO-TV in San Francisco announced that the station was "looking for unusual problems that can't seem to get resolved in usual ways." San Francisco Chronicle, Aug. 28, 1972, at 11, col. 5.

57. NewsweEk, Sept. 15, 1975, at 69-70. In another instance, a local lawyer worried that a newspaper action line was treading too close to the practice of law. He brought the issue to the state bar association; in response, the newspaper adopted the policy of excluding legal items from its action-line column. Bowler, Action Line Gets Answers, Colum. Journalism Rev., July/Aug. 1971, at 29, 32. One observer has suggested that to be safe, action lines should avoid giving specific answers to individuals' questions and instead devote themselves to general advice. See EDITOR \& Publisher, Nov. 15, 1969, at 56.

58. NewsweEK, Sept. 15, 1975, at 69-70. 
interests of the businesses about which complaints are received. ${ }^{59}$ Unless independent nonbusiness members are included in the governing structure of a complaint-processing organization, ${ }^{60}$ or unless its work is recorded on an open public record, such an organization has little incentive or power to address complaints by responsibly incorporating the consumer perspective.

Complaint mechanisms established and funded by government avoid the immediate pressure of conflicting interests. Yet, even though funds come from the taxpayer, they are funneled through legislatures in which business lobbies exert persistent influence. ${ }^{61}$ Key positions in public agencies are often filled by persons with close ties to the businesses under regulation. ${ }^{62}$ An informal channel may exist between jobs in an agency and jobs in the industry under surveillance. Staff loyalties are also colored by past experiences or hopes of future employment. ${ }^{63}$ In addition, mechanisms established by government to deal with complaints about government services resemble private industry efforts at self-regulation. Dependent on the government for its continued existence, a public complaint agency has little or no incentive to respond to grievances, and instead may divide the community,

59. Motivated by dwindling consumer confidence and by hopes of forestalling government regulation, business groups created and financed the $\mathrm{BBB}$ and trade-association complaint mechanisms. See Rosenthal Report, supra note 25, at 47,782 (describing origin of BBB); Greenberg \& Stanton, supra note 26 (describing trade association devices). The personnel of these organizations may be ardent consumer advocates, but their activities will be influenced by the continuing financial support of the businesses they are supposed to monitor. Moreover, the BBB is accorded little power; it forwards consumer complaints to the offending business, but cannot compel settlement. Instead, it relies on the business to resolve complaints voluntarily. Eaton, supra note 25.

Similarly, consumer action panels sponsored by trade associations chiefly transmit complaints from the consumer to the company and can only issue nonbinding, advisory opinions. The panels attempt to decrease consumer dissatisfaction without alienating the businesses that constitute their membership. Thus, they exist primarily to serve trade association members, not consumers. Greenberg \& Stanton, supra note 26.

60. An exceptional trade-association program, the Office of the Impartial Chairman (OIC), was authorized to resolve disputes within the moving industry in New York City through the use of binding arbitration. It helped to prevent complaints by screening the estimates of moving costs submitted by members of the industry. This organization differed in one crucial way from most trade association programs: it was set up jointly by the mover's trade association and a local chapter of the Teamsters Union. Responsive to a different constituency, OIC was given more power and independence than other systems, and was better equipped to respond to consumer interests. Greenberg \& Stanton, supra note 26.

61. 3 Senate Comm. on Government Operations, 95th Cong., 1st Sess., Study on Federal Regulation 1-22 (Comm. Print. 1977) (describing lobbying expenditures).

62. See R. Nold, Reforming Regulation 99-100 (1971); Robinson, The Federal Communications Commission: An Essay On Regulatory Watchdogs, 64 VA. L. Rev. 169, 185.93 (1978) (even when appointees are not from regulated industry, they seldom represent public interests; even if regulators are not captured by industry, regulation itself often is).

63. Serber, supra note 31 (personal and political connections between California's insurance-regulating agency and regulated insurance companies). 
lower complainants' expectations, and continue to be perceived as legitimate despite its inadequate resolution of complaints. ${ }^{64}$

\section{B. Monopoly, Power, and Public Scrutiny}

A complaint mechanism may also be able to insulate itself from complainants by monopolizing complaints. ${ }^{65}$ It may be the only organization receiving complaints in a given area or it may be sponsored by the only producer of the goods or services that engender complaints. A store that sells on credit and deals with customer complaints about payment terms has a near-monopoly on easy credit in the community. ${ }^{66}$ Thus, despite dissatisfaction, customers will return. The store's purpose is not to resolve complaints but to keep customers and to prevent their going elsewhere to complain. It achieves its purpose because of its market power and its ability either to pacify or to manipulate customers. $^{67}$

A similar phenomenon may explain some conduct of organizations like the PSB. ${ }^{.8}$ As the only bureau in the state that hears complaints about insurance companies, it has a monopoly on knowledge about such grievances. Perhaps due to its monopoly position, the PSB does not make complaint information public, and it thereby avoids public scrutiny of its conduct.

The UAW's mechanism for processing worker complaints ${ }^{69}$ is the

64. This pattern appeared in the conduct of the Service Area Committee (SAC), which is funded by the city government of Washington, D.C. SAC brings together community leaders and city agency personnel to discuss complaints about municipal services. Greenberg, supra note 33. Because SAC is dependent on the city for its continued existence and has little influence over resource allocation, it has been a largely inadequate mechanism for resolving complaints. Weekly meetings are congenial gatherings of wellintentioned people, all doing their best to solve problems. The informal atmosphere helps shift the focus from the formal rights of citizens and the duties of government, and lowers the expectations of community members. Community leaders tend to accept the rationalizations given by city officials who, in turn, often place blame on the community. In addition, SAC at times divides the community by causing local leaders to compete for limited resources. $I d$.

65. Problems arise even when there are many available third-party complaint handlers, because consumers cannot always determine which one to consult. Consequently, although diversity theoretically permits better choices, the consumer is unlikely to distinguish the truly helpful intermediaries from the crowd of worthless ones, particularly because complaint handlers sometimes change their names, or cease to exist.

66. See Greenberg, supra note 33. See generally D. Caplovitz, The Poor Pay More 15-30 (1967) (describing practices of retailers in low-income neighborhoods).

67. See Greenberg, supra note 33.

68. Serber, supra note 31. PSB rarely challenges the final arrangement that results from mediation between the complaining customer and an insurance company. PSB seldom requests public hearings, although it is authorized to do so. Furthermore, PSB's bias toward the insurance industry is apparent in its reluctance to launch investigations of large companies. Id.

69. See Combs-Schilling supra note 29. 
only forum within the union for the expression of worker grievances about the union; its use is intimately connected to the union's role as exclusive representative of the workers to the management. The mechanism is cumbersome and unresponsive, ${ }^{70}$ and workers have disincentives to complain during economic downswings. ${ }^{71}$

A striking contrast is offered by the complaint systems of department stores in one urban area. A study of six systems identified variations in their organization and concluded that persistent customers generally obtain satisfaction even if their complaints seem unreasonable. ${ }^{72}$ A major reason for this could be the face-to-face nature of department store complaint encounters. Such encounters may give the complainant an advantage over the individual who complains by mail or telephone. Another reason for success may be that department stores in competitive markets believe the benefits of keeping the steady customer satisfied are worth the costs.

\section{The Organization as Con Artist ${ }^{73}$}

Complaint intermediaries often serve the interests of organizations complained about by resolving only the most blatant cases of unfair treatment and by satisfying only the most persistent complainers. The intermediary diverts all but the real troublemakers and thus diffuses the anger felt by those whose complaints remain unaddressed. Through psychological ploys and functional unresponsiveness these intermediaries serve the interests of organizations stimulating complaints.

Third-party intermediaries, in contrast to in-house complaint departments, are particularly well situated to divert and pacify complainants. Third parties give a gloss of legitimacy to complaint handling; their apparent neutrality suggests an impartiality that puts the

70. See note 29 supra. From the perspective of the workers, "[t]he more paperwork involved, the less likely the men are to use the procedure." Combs-Schilling, supra note 29. There are also pressures from union officials that discourage worker complaints; one official observed that workers who complain are usually those who "kiss ass" with the company and are antiunion. Id. But the most entrenched disincentive derives from the union's position as the workers' exclusive bargaining representative. Most of a lineworker's grievances arise against the district committeeman who initially receives the worker's complaints. Because the worker cannot afford to alienate the committeeman, he is often forced to "lump" his grievance. $I d$.

71. Combs-Schilling found that union members used the complaint mechanism less in a period of economic hardship than in a period of relative economic health. See note 29 supra.

72. Karikas \& Rosenwasser, supra note 27.

73. This section draws on Goffman, On Cooling the Mark Out: Some Aspects of Adaptation to Failure, 15 Psych. 451 (1952), which identifies the elements of con artists' techniques and notes their appearance in other social interactions. For a persuasive account of the identical structure of con games and all commercial transactions, see A. LEFF, Swindling ANd Selling (1976). 
complainant off guard. As a result, the third party can often convince the complainant to drop the complaint or to accept a less than satisfactory resolution.

A kind of symbiosis exists between the organizations that provide goods and services and third-party complaint handlers. The organizations are the sources of problems that the third parties process, and the third parties help the organizations by managing the complaints. Most third parties are probably unaware of this functional fit; nonetheless, unresponsive complaint handling often serves the interests of the organization complained about.

Complaint mechanisms, whether run by third parties or by the offending organizations, can be unresponsive simply by making complaining difficult. Complex and time-consuming procedures ${ }^{7 t}$ that put the burden on the complainant at each successive step ${ }^{75}$ are likely to discourage individuals from bringing or pursuing grievances. Such obstacles and failure to monitor compliance in "settled" grievances ${ }^{76}$ may be part of a deliberate effort to placate the complainant until the grievance is no longer urgent and the complainant is ready to let it go. In another context, Goffman refers to this strategy as "cooling out." 77 The consumer is initially pacified with a sympathetic response; next, he is met with delay. As his frustrated expectations fade and his anger diminishes, the complainant may voluntarily give up. The strategies are to give the complainant hope in the beginning and then slowly take it away, ${ }^{78}$ or to symbolize concern while not accomplishing anything lasting. ${ }^{79}$ Other approaches let the complainant vent anger by exploding at the complaint handler, by making routine telephone calls, and by completing routine forms. Even if the problem is not resolved, the complainant feels better because he has done something and has been

74. For example, extensive paperwork is required by the UAW's Public Review Board procedures. See Combs-Schilling, supra note 29.

75. For example, trade-association consumer action panels transmit a complaint to the offending organization and take no further action until the consumer contacts the intermediary again. Greenberg \& Stanton, supra note 26.

76. Action lines, for example, rarely check to see if a complainant has been satisfied. See N.Y. Times, Mar. 29, 1976, at 31, col. 4.

77. Goffman, supra note 73, at 451-52. "Operators" cool out the "mark" or prospective victim of planned exploitation; "[a]n attempt is made to define the situation for the mark in a way that makes it easy for him to accept the inevitable and quictly go home." $I d$. at 452 .

78. See L. Nader, The Direction of Law and the Development of Extra-Judicial Processes in Nation State Societies, in Cross-Examinations: Essays 3 . M Memory of Max Gluckman 93-94 (P. Gulliver ed. 1978) (illustrating "hot-cold treatment" in linguistic techniques used by telephone supervisor to cool out complainant).

79. The SAC, see note 64 supra, was able to cool out complainants consistently by implementing "special projects" designed to demonstrate concern. The projects ultimately proved unsuccessful. See Greenberg, supra note 33. 
heard. He may even acquire a desired sense of control by viewing the act of dropping the complaint as his own calculated decision. ${ }^{80}$

The complaint processer may actively work to lower the complainant's expectations or to force him to reevaluate his initial sense of injustice. In some instances, informal meetings communicate a friendly atmosphere and an impression that all that can be done to solve the problem is being done. ${ }^{81}$ The intermediary actually may mislead the complainant to believe that all avenues of relief have been exhausted, ${ }^{82}$ or that the offending business practices are reasonable. The BBB, for example, may incorrectly tell a consumer that unwritten agreements are not binding and thereby persuade him that he has no basis for complaint. ${ }^{83}$ Short of dismissing the grievance altogether, the complaint handler often helps the complainant reformulate the grievance through a process variously called clarification, objectification, or interpretation..$^{84}$

By thus conveying problems "strip[ped] of their hostile emotional content"85 complaint handlers may cause consumers to reevaluate their initial feelings. In this process, the complaint handler may shift blame to the complainant. ${ }^{86}$ Further, the complainant may be blamed simply for complaining; for example, he may be told that he has no cause to complain. He may watch himself give up in the face of delays, and conclude it was petty to demand redress for a minor problem. He may learn to see people who complain as deviants. ${ }^{87}$ Indeed, in this culture, people are commonly reluctant to see themselves as complainers. ${ }^{88}$ This

80. If the complainant feels powerless in seeking satisfaction, he may rationalize his decision to give up as being at least one act within his own control.

81. Greenberg, supra note 33; see note 64 supra (complainants develop sympathetic attitudes toward those handling complaints in informal meetings).

82. Eaton, supra note 25.

83. Id. (customer billed for unwanted services was told relief unavailable absent written contract).

84. See Steele, Fraud, Dispute and the Consumer: Responding to Consumer Complaints, 123 U. PA. L. REv. 1107, 1156 (1975) (clarification, objectification); Mattice, supra note 34 (interpretative communication).

85. Steele, supra note 84 , at 1155 .

86. Greenberg describes how a sanitation department representative to a community complaint forum blamed the trash in vacant lots on the lack of community participation, when, in reality, the community was unable to discover procedures or times for trash removal. Greenberg, supra note 33.

87. Combs-Schilling found that reluctance to complain to the UAW's complaint mechanism was due in part to the negative image union members associated with complaining. Combs-Schilling, supra note 29. The peculiarly American value placed on selfreliance, see Hsu, American Core Value and National Character, in Psychological ANThropology 248 (F. Hsu ed. 1972), may contribute to the sense that complaining is an undesirable sign of weakness.

88. See Best \& Andreasen, supra note 13, at 720-21 (voicing complaint seems generally disfavored; complaining to third parties even more disfavored). One commentator has encouraged people to overcome the negative image of complaining: "Most of all, com- 
attitude accompanies what appears to be a pervasive perceptual handicap: the inability to identify individual complaints as part of an aggregate that calls for systemic response.

\section{Failure to See the Forest}

Individuals with complaints tend to think that they are alone, even when numbers of other people have the same problem. Perhaps this sense and the related reluctance to complain stem from a pattern linked with industrialization: the atomizing of the social organization into smaller and smaller consuming units. In addition, the demands of conformity-an equally powerful part of the American ideology-argue against identifying oneself as a troublemaker, even as others swallow the same complaints. ${ }^{\text {s9 }}$

In the context of complaint mechanisms, individuals tend to accede to the suggestion that their complaints are petty and not worth pursuing. ${ }^{00}$ Some, willing to see themselves as whistleblowers, may pursue their claims. Yet the prevailing rate of unsatisfactory resolution conveys the message that an individual complaint is generally not worth pressing. ${ }^{01}$ Reinforcing a sense of individual powerlessness, this failure rate may contribute to the view that only isolated individuals, as opposed to classes of people, have complaints.

One consequence is that only limited numbers of complaints are voiced, and these complaints do not provide strong pressures for systemic change. Even when large numbers of related complaints are ex-

plainers as individuals should not lose heart. They should learn to suppress that feeling of embarrassment, the worry about what other people will think of them." Baker, Time Essay: Louder! The Need to Complain More, TIME, July 3, 1972, at 33.

89. Tocqueville was one of the first to describe American intolerance of deviant behavior. See A. De Tocqueville, Democracy in AMerica 399-40 (J. Meyer \& M. Lerner cds. 1966) (immense power of public opinion in democracy).

90. This article has considered only a few of the possible sources of discouragement. Given a variety of pressures, a potential complainant may often decide to "exit" rather than "voice" his grievance. See A. Hirschman, Exit, Voice, AND Loyalty 105 (1970). Hirschman argues that decisions about whether to voice or to exit are related to perceptions of the probability of influencing a decision, of the calculated advantage of success, and of the availability of alternative products and services. $I d$. at $37-38,41$. The tendency to voice also depends on a population's general readiness to complain and on the availability of mechanisms for communicating complaints cheaply and effectively. $I d$. at $42-43$. The exercise of voice for handling everyday complaints can be treated as an index of the degree to which people believe they are powerful, regardless of the actual distribution of power in society. See L. Nader, Powerlessness in Zapotec and United States Societies, in The ANthropology of Power (R. Fogelson \&: R. Adams eds. 1977).

91. Best and Andreasen found that when consumers take their problems to third parties, they come away satisfied only one-third of the time. Best \& Andreasen, supra note 19 , at 125; see p. 1007 supra. 
pressed, most complaint handlers are not equipped to perceive or respond to group problems. ${ }^{92}$

Few federal agencies, for example, actually have offices responsible for handling citizen-initiated complaints; ${ }^{93} \mathrm{few}$ publicize their procedures or tabulate incoming complaints. ${ }^{94}$ One researcher noted that "[w]ithout statistical records of the nature, categories, frequencies, distributions, and dispositions of complaints, agencies can hardly be expected to integrate complaint data into their regular operations or sustain standards of meritorious performance in their direct relationship with the public." ${ }^{95}$ It is not surprising, then, that federal agency practices are seldom changed in response to complaints. ${ }^{96}$

Other complaint mechanisms fail to respond to problems in the aggregate because they are not empowered to do so or because it is not in their own interest to respond with systemic reforms. Some mechanisms, particularly those created as a form of self-regulation, lack any authority to resolve complaints and simply act as couriers that carry complaints to the proper party ${ }^{97}$ Lacking sufficient ties to the parties they are supposed to scrutinize, ${ }^{98}$ these intermediaries do not have the structural capacity to respond to problems on an aggregate level. Some complaint handlers shy away from challenging general practices in order to garner enough power to achieve success in individual cases. ${ }^{99}$ Others, fully aware of their limited authority, may even try to separate complainants who initially come to them with shared interests. ${ }^{100}$ Such intermediaries hold little authority or power and must depend on unobtrusive, uncontroversial measures. The grant of little authority is often due to the presence of interests more powerful than the consumer or citizen groups supposedly served by complaint programs. ${ }^{101}$

92. See, e.g., Steele, supra note 84 , at $\mathbf{1 1 8 0 - 8 6}$ (Illinois Consumer Fraud Bureau primarily solves concrete disputes rather than enforcing antifraud laws systemically).

93. One study found that of 64 agencies responding to a questionnaire, 51 reported having no office specifically responsible for handling citizen-initiated complaints, aside from formal adjudicative procedures. Rosenblum, Handling Citizen Initiated Complaints: An Introductory Study of Federal Agency Procedures and Practices, 26 AD. L. REv. 1, 10 (1974).

94. Id. at 10-12.

95. Id. at 12 .

96. Id. at 11 .

97. For example, the BBB and the complaint panels created by trade associations for the most part simply carry complaints to the offending business. See note 59 supra.

98. In fact, most trade-association mechanisms represent less than half of their particular industry. As a result, they are hampered from fulfilling even the limited task of conveying complaints to the proper parties. See Greenberg \& Stanton, supra note 26.

99. The Community Development Group, a private service organization in Washington, D.C., relies on the influence it gains through informal contacts with public agency personnel to facilitate certain cases. Therefore it refrains from aggressive challenges to the agencies. See Greenberg, supra note 33.

100. See note 64 supra.

101. See pp. 1009-11 supra. 
Some complaint mechanisms do not gather or respond to complaints on an aggregate basis even when they have the power to act systemically. Media action lines are a prime example. Capable of arousing public pressure and generating group consciousness, ${ }^{102}$ media organizations are fundamentally limited by dependence on audience interest and advertiser support. These limitations often impede systemic reforms, ${ }^{103}$ even though media action lines remain one of the most effective complaint handlers outside of courts.

Another effective complaint handler, a congressman, was free of conflicting interests and depended to a great extent on the satisfaction of complaints for reelection. ${ }^{104}$ In a sense, the congressman had a stake in the continuation of his constituent's problems. ${ }^{105}$ For his own political survival, it made sense to respond on a case-by-case basis, rather than to push legislative action. Even in relation to problems potentially shared by a class of constituents, such as recipients of social security or veterans benefits, the congressman guaranteed votes by arranging for individualized relief.

Most intermediaries screen complaints in order to select those that should be addressed. Although they are meant to serve as alternatives to law, complaint processors often screen out complaints that do not raise legal claims. Moreover, complaint handlers sometimes screen complaints according to the personal characteristics of the complainant. The PSB, for example, pays more attention to the complainant who is calm, articulate, white, male, and middle-class than to the excited, nonwhite, or female complainant. ${ }^{106}$ Intermediaries may try to determine whether the subject of the complaint is "important" or "valid"; they may reject a case that appears complex and costly to process.

This ad hoc approach to complaint handling permits unfair treatment and fails to stimulate extensive reforms. Secrecy, intimidation, and distancing mechanisms all protect self-interested groups. Rather than responding to all complainants, grievance organizations find it less expensive to treat isolated cases and to allow complainants to drop

102. One complainant reported that she persevered in her complaint about a particular brand of stove when she received supportive letters from other purchasers following a newspaper story about her complaint. Citation withheld to protect confidentiality.

103. See p. 1009 supra.

104. Karikas, supra note 30 . The need to cultivate votes gave the congressman a direct incentive to aid complainants; the need to develop helpful local contacts to ensure his ability to solve complaints gave him reason to lobby in Washington for the local industries that assisted his constituents. Id.

105. See W. GellhorN, supra note 30, at 75-76 (congressional representatives respond to constituent complaints to help themselves get reelected).

106. Serber, supra note 31 ("deselection" of complaints based on complainants' sex, race, affluence, articulateness, and degree of calm). 
their grievances or to avoid voicing them; yet the costs of this approach are real, if sometimes hidden, and they are pervasive.

\section{E. The Costs of Inadequate Complaint Processing}

The immediate cost of inadequate complaint processing is borne by the consumer. If his complaint remains unsatisfied, he continues to suffer the injustice that stimulated it, as well as cumulative effects of that injustice. Particularly if the complainant is poor, even a small dollar loss can be serious. Individuals of any income level are not immune to larger costs such as those associated with defects in automobiles, mobile homes, or nursing home services.

The psychological strains of living with an unreliable product or service $^{107}$ are compounded by the emotional toll of the complaint process itself. Delays and confrontations accompany even responses to complaints that are finally successful; unsuccessful complainants have to deal with increased frustration and humiliation, even when "cooled out" by the intermediary. The consequent sense of powerlessness is a cost to both the individual and society. ${ }^{108}$ People who feel powerless tend to become apathetic and uninvolved. This response short-circuits the ideal chain of communication that could alert producers of goods and services to defects and inefficiencies.

As a result, the kind of information loop that could improve products and services does not develop, and instead an inefficient and unsuccessful process of chain referrals is maintained. The cost of dealing with an average product or service failure is often as large or larger than the original purchase price and consumers absorb the greater part of such costs. Effective complaint resolution would cause firms to internalize these costs when they make repairs, replacements, or refunds. Thus they would have a stronger incentive than they do now to improve the quality of products and services. In other words, mass redress of individual consumer complaints could have a powerful effect in improving the quality of American products. Further, institutions for which complaint handling is only a secondary function could then devote more time to the performance of their primary tasks.

107. Even though small amounts of money may be involved, the breakdown of a washing machine can be a real crisis for a family without an automobile. A low-income individual who refuses to pay a bill for a defective item may face the possibility of garnishment of his wages. A delay in repairing a set of false teeth has emotional costs for a patient that exceed the money involved. See note 17 supra.

108. The Small Claims Study Group concluded that small grievances "are the stuff of everyday life and the outcome of the attempt to redress them has much to do with whether people feel empowered, active agents controlling their own destinies, or exploited, victims of forces beyond their control." Small Claims Study Group, supra note 17, at 9. 
Some observers have suggested that the cumulative effect of little injustices is endemic lawlessness. ${ }^{109}$ Even if complaint mechanisms do not cause disorder and lawlessness, they fail to help remedy the corruption and ineptitude of landlords, loan sharks, health inspectors, public service bureaucrats, and private producers. One obvious reform would be to increase the role of law in addressing the low-profile, petty exploitation suffered by large segments of the population. But that solution, most often associated with the small claims court movement, has also failed to realize stated goals. ${ }^{110}$

\section{Complaints and the Law}

Several concluding observations result from the studies of alternatives to courts that have been described here. First, the relative power between purchasers and providers is a key variable with respect to the ability of nonjudicial complaint mechanisms to resolve disputes satisfactorily. ${ }^{111}$ The fundamental problem that constrains the performance

109. See, e.g., P. Schrag, Counsel FOr THE Deceived (1972). Schrag, a professor at Columbia Law School, described his attempts to deal with everyday problems in New York City. He perceived a breakdown in law evidenced by nonenforcement of consumerprotection legislation.

110. See Yngvesson \& Hennessey, supra note 5, at 268 (small claims courts remain ineffective for poor).

111. The relative bargaining power of the parties can determine the fairness of the terms of the exchange. The law has already recognized the danger of a "contract of adhesion," described as

a standardized contract proposed entirely by one party to the transaction for the acceptance of the other; such a contract, due to the disparity in bargaining power between the draftsman and the second party, must be accepted or rejected by the second party on a "take it or leave it" basis, without opportunity for bargaining and under such conditions that the "adherer" cannot obtain the desired product or service save by acquiescing in the form agreement.

Steven v. Fidelity \& Cas. Co., 58 Cal. 2d 862, 377 P.2d 284, 27 Cal. Rptr. 172 (1962) (citations omitted).

Courts have used the unconscionability clause of U.C.C. $\$ 2.302$ to invalidate onerous provisions of such contracts. See, e.g., Williams v. Walker-Thomas Furniture Co., 350 F.2d 445 (D.C. Cir. 1965); Zabriski Chevrolet, Inc. v. Smith, 99 N.J. Super. 441, 240 A.2d 195 (Super. Ct. Law Div. 1968). As one critic noted, however, contract remedies secured through adjudication do not address the "inefficiencies and inequities of exorbitant prices and oppressive clauses" of form contracts. Kornhauser, Unconscionability in Standard Forms, 64 Calif. L. Rev. 1151, 1183 (1976). Nor are judicial remedies responsive to those who do not sue because they do not expect relief or to those who decide not to purchase because of unfair contract terms. Id. at 1180 .

Unequal bargaining power is especially troubling when the seller uses vastly unequal bargaining power to disclaim warranties or limit remedies. See Henningsen v. Bloomfield Motors, Inc., 32 N.J. 358, 404, 161 A.2d 69, 95 (1960) ("The lawmakers did not authorize the automobile manufacturer to use its grossly disproportionate bargaining power to ... impose on the ordinary buyer, who in effect has no real freedom of choice, the grave danger to himself and others that attends the sale of such a dangerous instrumentality as a defectively made automobile.") Legislative efforts to protect consumers against such harm include 15 U.S.C. $\$ \S 2301-2312$ (1976), which requires that warranties for con- 
of alternative complaint mechanisms today derives from their inability to compensate adequately for the ineffective bargaining position of the individual who confronts large corporations and government bureaucracies. Many complaint handlers reinforce these unequal bargaining positions; others are powerless to reorder them. Disputes between people of unequal power are unlikely to be settled fairly by mediation or arbitration unless the force of law is available as a last resort. ${ }^{112}$

Courts should be available, especially in cases in which the parties have unequal power; parties with relatively equal power are more likely to resolve disputes without the aid of the judiciary. Access to court for parties of unequal power could itself shape opportunities for satisfactory settlement without the exercise of legal authority. Even now, settlements of claims that could have been resolved legally almost universally reflect the level of awards available in small claims court. ${ }^{113}$ Expanding judicial relief for minor claims could lead to better nonjudicial solutions.

A second observation is that no matter how alternative complaint mechanisms are strengthened, their case-by-case approach cannot remedy all the harms identified by consumer and citizen complaints. Expanding automatic return policies, simplifying small claims court, and extending consumer arbitration in the shadow of the courtroom door are reforms that would provide some limited relief, but they would not contribute to the identification of widespread problems or to the prevention of future disputes. Only when numerous complaints are viewed together can a pattern emerge-for example, a pattern of automobile-repair fraud. Handling such complaints in the aggregate may lead to effective preventive reforms; it may also be less expensive than a case-by-case approach. Aggregate solutions are available through classaction litigation and regulation, ${ }^{114}$ yet business and government, for the most part, do not construct aggregate solutions to classes of complaints and instead persist in approaching each grievance individually.

Ways must be found to compensate for the perceptual handicap that

sumer products be more readily understandable and enforceable by the consumer. This statute ultimately may fail to serve consumer interests because its provisions could encourage sellers to issue oral warranties that are difficult to enforce or to issue limited rather than full warranties. Hymson, The Magnuson-Moss Warranty-Federal Trade Commission Improvement Act: Should the Consumer Rejoice? 15 J. FAM. L. 77 (1976).

112. Giving parties access to court ensures that they have an effective technique to resolve their dispute; access may also influence the way in which the same problems are resolved out of court. See Lempert, Mobilizing Private Law: An Introductory Essay, 11 LAw \& Soc'y REv. 173, 173-74 (1976).

113. L. Nader \& Shugart, in No Access to Law (chapter 2, untitled).

114. But see note 4 supra (noting barriers to class-action litigation and limitations of regulation). 


\section{Disputing Without Law}

so often restricts problemsolving to this case-by-case approach. ${ }^{115}$ One technique would start with the recognition that, as in most cultures, the most powerful tool of law reform is public opinion. The mass nature of this society requires the use of innovative techniques to inform and rally public opinion. Although seldom employed for this purpose, existing communication technologies could be used to publicize the records of varied complaint organizations. Such records could be published; complaints could be metered or banked. ${ }^{116}$ Further, if all public and private complaint organizations were required to have open records, strategies for aggregate reform could be formulated more easily.

A third observation is an initial response to the question posed at the beginning of this article: are problems of access to law causing a serious deficiency in our justice system? The answer is yes. Estimates of the economic and psychological costs of unattended complaints can only hint at the loss to society that results when little injustices accumulate without judicial relief. Yet the courts are unable to provide complete justice even to those who enter their doors. A comparison of two trial courts in California between 1890 and 1970 concludes that the function of courts has changed from dispute settlement to routine administration. ${ }^{117}$ The institutions that have replaced the courts, some of which have been described here, do not operate very well for the powerless.

Disputing without law is not a very satisfactory experience for most consumers and citizens in this country, yet it is unlikely that the force of law can be marshaled to address "little injustices" unless they are reconceptualized as collective harms. For official action in that direction to have any likelihood of yielding more than symbolic victories, an active and vital grass-roots citizen and consumer movement must be encouraged.

115. See pp. 1015-18 supra.

116. L. Nader \& Singer, Dispute Resolution ... Law in the Future: What are the Choices? 51 CAL. ST. B.J. 281,314 (1976).

117. Friedman \& Percival, $A$ Tale of Two Courts: Litigation in Alameda and San Benito Counties, 10 LAW \& Soc'y REV. 267, 302 (1976). 


\section{The Yale Law Journal}

Volume 88, Number 5, April 1979

\section{Paul M. Smith \\ Editor-in-Chief}

Edward L. Rubin

Note \& Topics Editor

Stephen L. Carter

Susan L. Hoffman

Gerson A. Zweifach

Note Editors
Lee J. Levine

Managing Editor

Kim J. Landsman

Martha L. Minow

James F. Strnad II

Article \& Book Review

\section{Editors}

Sheldon S. Adler

Michael J. Album

Peter A. Barnes

Joel S. Beckman

Daniel J. Broderick

Donald F. Brosnan

James J. Brudney

Sarah E. Burns

William C. Campbell

Mark S. Campisano

Peter C. Canfield

William W. Chip

Alice Armitage Colburn

David M. Crowe

Lant B. Davis

Richard H. Fallon

Boris Feldman

David W. Ferguson
Michael A. Fitts

Morgan J. Frankel

Eric M. Freedman

A. Ann Fruman

James A. Geraghty

R. Laird Hart

Courtney W. Howland

Gary S. Katzmann

Robert A. Katzmann

Reinier H. Kraakman

Bruce R. Kraus

John J. Kulewicz

William L. Lynch

Scott M. Matheson

Sonia Sotomayor

de Noonan

Karen L. Peterson

Russell V. Randle
Roberta Romano Kenneth T. Roth Anne C. Ryan Joseph J. Sheehan John H. Small James C. Snipes Michael G. Starr Susan P. Sturm Bruce C. Swartz Gary C. Tepper Debra A. Valentine Daniel M. Waggoner Anne S. Wallwork Richard C. Weisberg Ellen Wertheimer David J. Wohlberg Robert R. Wootton Ellen E. Wright

Secretaries to the Editors M. Olive Butterfield, Pamela Willmott

\section{Student Contributors to This Issue}

Reinier H. Kraakman, Article III Constraints and the Expanding Civil Jurisdiction of Federal Magistrates: A Dissenting View

Susan P. Sturm, "Mastering" Intervention in Prisons 